\title{
A study on antibacterial activity of Pavoniazeylanica of Malvaceae family
}

\section{Authors \& Affiliation:}

Joga Rao Y S V S ${ }^{1,2}$,

Annasamuel Lanka²,

H B Bollikolla ${ }^{1 *}$,

Ramachandran $\mathrm{D}^{1 \dagger}$

${ }^{1}$ Department of Chemistry, Acharya

Nagarjuna

University,Nagarjunanagar, Guntur,

AP-India

${ }^{I}$ Department of Chemistry, Rajah $R S$

R K R RCollege, Bobbili,

Vizianagaram Dist., AP-India

\section{Corresponding Author}

$$
\begin{aligned}
& \text { H B Bollikolla }{ }^{1 *}, \\
& \text { Ramachandran } \mathrm{D}^{1 \dagger}
\end{aligned}
$$

*Email:dittakavirac@gmail.com;

\section{drharibabuanu@gmzil.com}

Article received: 25.07.2019

Article accepted: 20.12.2019

(C) 2019.The Authors. Published under Caribbean Journal of Science and Technology

ISSN 0799-3757

$\underline{\text { http://caribjscitech.com/ }}$

\begin{abstract}
:
The current paper is focused on screening of antibacterial activity of extractsof the leaves of $P$. zeylanica. Initially the plant leaves were collected, dried and extracted with the solventsn-Hexane, ethylacetate, chloroform, ethanol, methanol and water. Further, the crude extracts were studied for theirantibacterial potentiality on nine different bacteria. Among them methanol extract was found to possess highest MIC of $1.25 \mathrm{mg} / \mathrm{mL}$ on bacteria Salmonella Entericatyphimurium, Vibrio Cholerae and AcinetobacterBaumannii.
\end{abstract}

Keywords: Phytochemical Screening; Antibacterial activity; MIC;Pavoniazeylanica

Human life has many challenges but every challenge has its own answer in the nature. Best things in the life offered by nature are accessible free anytime. Every man's basic needs are within his grasp. Man always can stretch out and take use of nature's vast resources.Now a days plants are using and testing for various purposes ${ }^{1-}$ ${ }^{6}$. Nature provides medicinal remedies for all kinds of diseases. The current paper explores this rich therapeutics available in provenance of P.zeylanica(Fig. 1). The plant $P$. zeylanica also known as Ceylon Swamp Mallow ${ }^{7}$. It is branched, stubby, large herb, grows up to 1-1.5 meters. Hairs have been found on Stem, leaf and flower-stalks. Leaves are 1.5-3 cm long, 1-2.5 cm broad and Lance-shaped to ovate. However, lower leaves are 3-lobed and lobes oblong or obviate. Leaf stalks are of 1$4.5 \mathrm{~cm}$ long. Flowers are found singly in leaf axils and are about $1.5 \mathrm{~cm}$ long and pink in color. The length of flower stalk is about 2-4 cm long. Sepals are lanceshaped. Fruit is velvey, spherical and about $5 \mathrm{~mm}$ fig1. This shrub is mainly found in the countries like Srilanka, India, Pakistan, Arabia, and Tropical Africa.

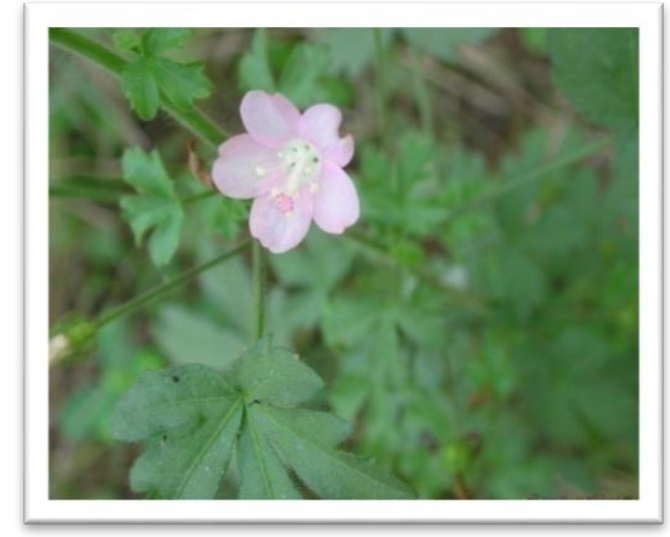

Fig. 1: P.zeylanica 
The root is washed and boiled to prepare a decoction. This preparation is thoroughly sieved, and used to control dysentery, and abdominal pain. The root decoction with turmeric is also used to subside itching. Paste made with fresh young leaves is applied over wounds as an ointment to control inflammation and other skin infections.

\section{Materials and Methods:}

Initially, the plant was collected at surroundings of Bobbili (Jogimpeta village about $15 \mathrm{Km}$ from Bobbili of Vizianagaram District, AP-India. Further, the plant was authenticated by the taxonomist in the department of Botany of Acharya Nagarjuna University, AP-India. The plant sample was first properly washed and shade dried and powdered. Later, the powdered sample was subjected to soxhlet extraction. Hundred grams of dry plant powder was packed in filter paper according to size of thimble and kept in thimble of soxhlet. In the extraction process, solvents of different polarities from low polarity to high polarity namely $n$-hexane, ethylacetate, chloroform, ethanol, methanol and water were used. Temperature of $40-60{ }^{\circ} \mathrm{C}$ was maintained during the extraction and the process continued until solvent in the thimble become clear. Percentage of yield was calculated per $100 \mathrm{gm}$ of dry plant powder and tabulated in Table 1.

Table 1:Extraction by Soxhalation

\begin{tabular}{|l|l|l|}
\hline Sl. No & Solvent Extract & $\begin{array}{l}\text { Yield } \\
\text { (percentage w/w in gm) }\end{array}$ \\
\hline 1 & n-Hexane & 0.9 \\
\hline 2 & Ethylacetate & 1.1 \\
\hline 3 & Chloroform & 2.4 \\
\hline 4 & Ethanol & 6.1 \\
\hline 5 & Methanol & 16.4 \\
\hline 6 & Water & 12.4 \\
\hline
\end{tabular}

In the present study the authors made an attempt to screen the plant extracts for their antibacterial properties on nine various bacterial strains selected based on the diseases treated by the traditional healers on regular basis. In this investigation of antibacterial properties, several standard assays are being used in this investigation. The present investigation used the agar gel well diffusion methodology ${ }^{8}$, which is carried out in accordance well with National Committee for Clinical Laboratory Standards' recommendations (NCCLS, 2012). In a photoelectric spectrophotometer around $520 \mathrm{~nm}$, the 24 hour aged $1 \mathrm{ml}$ bacterial culture is combined with sterile physiological saline - 0.9 percent and also the OD result is calibrated to $0.5 \mathrm{McFarland}$ units of optical density of 90percentage transmittance ${ }^{9,10}$. Bacterial strains quantification were completed ${ }^{10,11}$.

The Mueller-Hinton agar medium is used to make nutrient agar plates via the Pour plate approach. The medium is retained at a temp of 40-45 degrees Celsius. Afterwards $1 \mathrm{~mL}$ of the matching bacterium's growing culture is well combined, placed onto a sterile flat-bottomed petri - dish of dimension 9x1.5 cm diameter, and allowed to solidify. Antibacterial agents are loaded into wells created with the aid of something like a sterile cork borer - the plant extracts. The well dimension is limited to 6 millimetres, and each plate has six wells. Burrowing of wells has already been done with caution, because as size $\&$ form of the well influences the rate of diffusion ${ }^{10}$. The bacterial cultures provided in Table 2 were acquired from Institute of Microbial Technology - IMTECH at Chandigarh, India (Customer number: 7056, S. T no 2716RSTOO5).

A micropipette is utilized to inoculate 20 microliters of plant extract $(5 \mathrm{mg} / \mathrm{mL}$ concentration) inside each well. To prevent infection, the points are kept sterile. The Petri-plate is set aside for the next few minutes to allow the sample taken to diffuse adequately within the well. The plate is subsequently covered with paraffin \& maintained in an incubator overnight at $35^{\circ} \mathrm{C}$. All of the plates are created in threes.For easier interpretation, the antibiotics azythromycin\& amoxicillin are employed as positive controls, while the corresponding solvents have been used as negative controls. The extract of plants, which acts as just an antibacterial agent, produces a clean zone 
surrounding the well where bacteria can not thrive ${ }^{12}$. The Inhibition zones is the name given to this clean area. The outcome is provided in millimeters and is quantified using Himedia's developed zone of inhibition scale.

The RPI - Relative Percentage Inhibition, is computed by correlating the inhibition zones of two common antibiotics (azythromycin\& amoxicillin) with inhibition zones of a plant extract over the same bacterial strain. For calculations, the below formula is used ${ }^{13}$ (Naz and Bano, 2012).

In which, $\mathrm{X}$ - inhibition zone of a plant extract

$$
\text { RPI of a plant extract }=\frac{(X-Y) * 100}{(Z-Y)}
$$

Y- Totalinhibition zone area of solvent

$\mathrm{Z}$-Total inhibition zone of standard antibiotic.

\section{Results and Discussion:}

All the six extracts were studied for their antibacterial properties by Agar gel well diffusion method ${ }^{14}$. The mean zone of inhibition values were measured with standard deviation. The antibacterial activity was measured with above said six different extracts, against four Gram-positive bacterial strains and five Gram-negative strains. Among them three extracts namely Ethyl acetate, Ethanol and Methanol were found to possess prominent antibacterial activities and the results were tabulated in Table 2.

Among these three extracts, highest activity was found with methanol extract (ranging from $13.0 \pm 0$ to $22.6 \pm 0.57)$ against different bacteria studied. Highest zone of inhibition was detectedalongsideV. cholerae (22.6 \pm 0.57$)$ (Fig. 2). Alternative extracts (ethanol \& ethyl acetate) had a modest inhibition zone over gram positive $\&$ negative bacteria, spanning between $11.60 \pm 5$ through $17.66 \pm 1$. N-hexane extract, on the other hand, showed no inhibition zone against with the microorganisms tested. As a result, the current investigation concludes as Gramnegative bacteria are much more vulnerable to $P$. zeylanica methanol extract over Gram-positive bacteria.

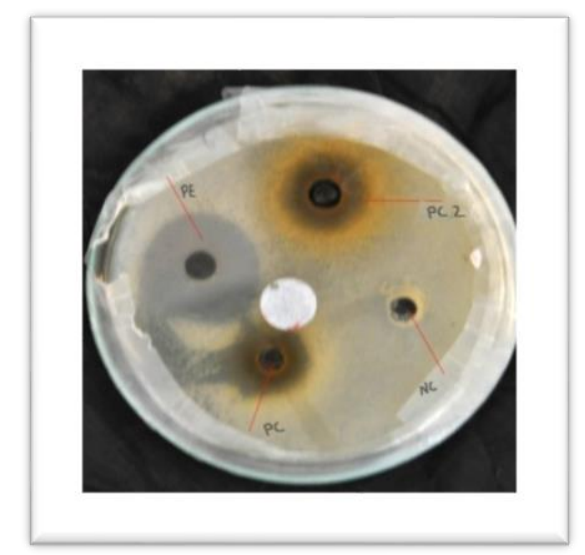

Figure 2: Antibacterial activity of P.zeylanicaagainst V.cholereae 
Table 2:Antibacteiral screening of different extracts $P$. zeylanica

\begin{tabular}{|c|c|c|c|c|c|c|c|c|c|c|}
\hline \multirow[t]{2}{*}{$\begin{array}{l}\mathrm{S} \\
\text {. } \\
\mathrm{N} \\
\mathbf{0}\end{array}$} & \multirow[t]{2}{*}{$\begin{array}{c}\text { Name of } \\
\text { the } \\
\text { extract } \\
\text { Used }\end{array}$} & \multicolumn{8}{|c|}{$\begin{array}{l}\text { Inhibitionzone ( diameter in mille meters }(\mathrm{mm}) \text { ) over different Bacteria } \\
(\text { Mean } \pm \text { standard deviation). } \\
\text { Plant extracts Concentration } 5 \mathrm{mg} / \mathrm{ml} \text {. }\end{array}$} & \multirow[b]{2}{*}{$\begin{array}{c}\text { Klebsiellapneu } \\
\text { moniae }\end{array}$} \\
\hline & & $\begin{array}{c}\text { Staphyloc } \\
\text { occus } \\
\text { aureus }\end{array}$ & $\begin{array}{c}\text { Bacillus } \\
\text { coagula } \\
\text { ns }\end{array}$ & $\begin{array}{l}\text { Streptoco } \\
\text { ccus } \\
\text { pyogenes }\end{array}$ & $\begin{array}{c}\text { Streptoco } \\
\text { ccus } \\
\text { pneumon } \\
\text { iae }\end{array}$ & $\begin{array}{c}\text { Salmone } \\
\text { lla } \\
\text { enteric } \\
\text { typhimu } \\
\text { rium }\end{array}$ & $\begin{array}{l}\text { Vibrio } \\
\text { cholera }\end{array}$ & $\begin{array}{c}\text { Acinetobacterba } \\
\text { umannii }\end{array}$ & $\begin{array}{c}\text { Pseudom } \\
\text { onas } \\
\text { aerugino } \\
\text { sa }\end{array}$ & \\
\hline \multirow{3}{*}{1} & $\begin{array}{l}\text { Ethyl } \\
\text { acetate }\end{array}$ & $11.6 \pm 0.5$ & $\begin{array}{c}10.6 \pm 0 . \\
57\end{array}$ & $11.0 \pm 0$ & $\begin{array}{l}10.8 \pm \\
0.76\end{array}$ & $\begin{array}{c}15.8 \pm 0 . \\
76\end{array}$ & $\begin{array}{c}14.0 \pm \\
0\end{array}$ & $15.66 \pm 0.5$ & $\begin{array}{l}12.0 \\
\pm 0.5\end{array}$ & $\begin{array}{c}14.0 \pm \\
0.5\end{array}$ \\
\hline & Ethanol & $\begin{array}{c}12.3 \pm 0.5 \\
7\end{array}$ & $\begin{array}{c}13.66 \pm \\
0.57\end{array}$ & $\begin{array}{l}11.66 \\
\pm 0.57\end{array}$ & $13 \pm 1$ & $\begin{array}{c}18.6 \pm 0 \\
57\end{array}$ & $17 \pm 0$ & $\begin{array}{c}18.3 \\
\pm 0.57\end{array}$ & $17.0 \pm 0$ & $17.66 \pm 1$ \\
\hline & Methanol & $13.0 \pm 0$ & $\begin{array}{c}15.3 \pm 0 \\
57\end{array}$ & $15.0 \pm 0$ & $\begin{array}{c}14.3 \pm \\
0.57\end{array}$ & $\begin{array}{c}21.6 \pm 0 . \\
57\end{array}$ & $\begin{array}{c}22.6 \pm \\
0.57\end{array}$ & $\begin{array}{c}20.6 \\
\pm 0.57\end{array}$ & $\begin{array}{c}18.6 \\
\pm 0.57\end{array}$ & $18.0 \pm 0$ \\
\hline \multirow{2}{*}{2} & $\begin{array}{l}\text { Azythro } \\
\text { mycin } \\
\text { (Positive } \\
\text { control) }\end{array}$ & $17.8 \pm 0.7$ & $12 \pm 0.5$ & $13 \pm 0.5$ & $22 \pm 0$ & $22 \pm 0$ & $20 \pm 0$ & NA & NA & $\begin{array}{c}27.5 \pm \\
1.0\end{array}$ \\
\hline & $\begin{array}{l}\text { Amoxicil } \\
\text { lin } \\
\text { (Positive } \\
\text { control) }\end{array}$ & $15 \pm 0$ & $16 \pm 1.7$ & $23 \pm 0$ & $\begin{array}{l}27.8 \\
\pm 0.7\end{array}$ & $20 \pm 0$ & $18 \pm 0$ & $22 \pm 0$ & NA & $28 \pm 0.5$ \\
\hline
\end{tabular}

$P E=$ plant extract; $P C 2=$ positive control (Azythromycin), $P C 1=$ positive control (Amoxicillin), NC=Negative control.

It is being done to see how effective plant extracts are compared to conventional antibiotics. The antibacterial action of such plant extract was compared to that of two antibiotics, Azythromycin and Amoxicillin, with the findings represented as relative percentage inhibition.(RPI). Results were tabulated in Table 3 . The highest RPI (methanol extract) than Azythromycin was observed against Bacillus coagulans (127.5 \%) S.pyogenes(115.38 $\%)$ and V.cholerae $(113.0 \%)$. The antibiotic azythromycin had a lower inhibition zone than that of the other bacterial strains there in research. Methanol extract had a relative percentage inhibition of 125.55 percent over V.cholerae and 108.00 percent over S.typhi when compared towards the antibiotic amoxicillin. With certain other bacterial strains, the plant extract demonstrated a lower inhibition zone to amoxicillin.

Remarkably, P. zeylanica extract showed its doingsalongside bacteria, A. baumannii $(20.6 \pm 0.57 \mathrm{~mm})$ and P.aeruginosa $(18.6 \pm 0.57 \mathrm{~mm})$, where standard drugs were found to be fruitless. Resistance was exhibited byA. baumannii, with azythromycin whileP.aeruginosa showed resistance to the two antibiotics. This is a hallmark to express the potency. The minimum concentration of plant extract that hinders bacterium growth is referred to as MIC. It ensures efficacy of plant extract as antibacterial therapeutics. Macro dilution method was used to calculate MIC extract against nine bacterial strains in the study. The results were presented in Table4. 
Table 3: P. zeylanica Relative Percentage Inhibition (RPI)

\begin{tabular}{|c|c|c|c|c|c|c|c|}
\hline $\begin{array}{l}\mathbf{S} \\
\mathbf{N} \\
\mathbf{0}\end{array}$ & $\begin{array}{c}\text { Bacteri } \\
\text { a - } \\
\text { Name }\end{array}$ & $\begin{array}{c}\text { Inhibitionzon } \\
\text { e of } \\
\text { Methanol } \\
\text { Extract }=X\end{array}$ & $\begin{array}{c}\text { Inhibitionzone } \\
\text { of } \\
\text { Azythromycin= } \\
\mathrm{Z}\end{array}$ & $\begin{array}{c}\text { Inhibitionzon } \\
\text { e of } \\
\text { Amoxicillin= } \\
Z\end{array}$ & $\begin{array}{l}\text { Inhibitionzon } \\
\text { e of pure } \\
\text { solvent } \\
\text { (Methanol) } \\
\text { =Y }\end{array}$ & $\begin{array}{l}\text { RPI of plant extract } \\
\text { withAzythromycin } \underline{(X} \\
\frac{-\mathbf{Y}) \mathbf{X} 100}{(\mathbf{Z} \cdot \mathbf{Y})}\end{array}$ & 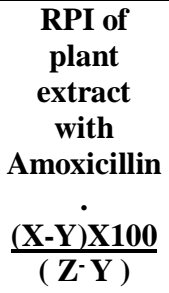 \\
\hline 1 & S.a & 13.0 & 17.8 & 15.0 & 0 & 73.03 & 86.66 \\
\hline 2 & B.c & 15.3 & 12.0 & 16.0 & 0 & 127.5 & 95.62 \\
\hline 3 & S. py & 15.0 & 13.0 & 23.0 & 0 & 115.38 & 65.21 \\
\hline 4 & S. pn & 14.3 & 22.0 & 27.8 & 0 & 65.00 & 51.43 \\
\hline 5 & S. $\mathrm{t}$ & 21.6 & 22.0 & 20.0 & 0 & 98.18 & 108.00 \\
\hline 6 & V.c & 22.6 & 20.0 & 18.0 & 0 & 113.00 & 125.55 \\
\hline 7 & A. b & 20.6 & NA & 22.0 & 0 & CND & 93.63 \\
\hline 8 & P. a & 18.6 & $\mathrm{NA}$ & NA & 0 & $\overline{C N D}$ & CND \\
\hline 9 & K.p & 18.0 & 27.5 & 28.5 & 0 & 65.45 & 63.15 \\
\hline
\end{tabular}

$\mathrm{Sa}=$ Staphylococcus aureus, B.c= Bacillus coagulans, pseudo tuberculosis,S.py= Streptococcus pyogenes, S.pn= Salmonella entericatyphimurium, V.c = Vibrio cholerae, $A b=$ Acinetobacterbaumannii, $P a=P$ seudomonas aeruginosa, K. $p=k l e b i s e l l a p n e u m o n e a e, ~ N A=N o$ Activity. $C N D=$ Cant not detected $\mathrm{x}=$ zone of inhibition of a plant extract, $\mathrm{Y}=$ total zone of inhibition area of solvent, $\mathrm{Z}=$ total zone of inhibition of standard antibiotics.

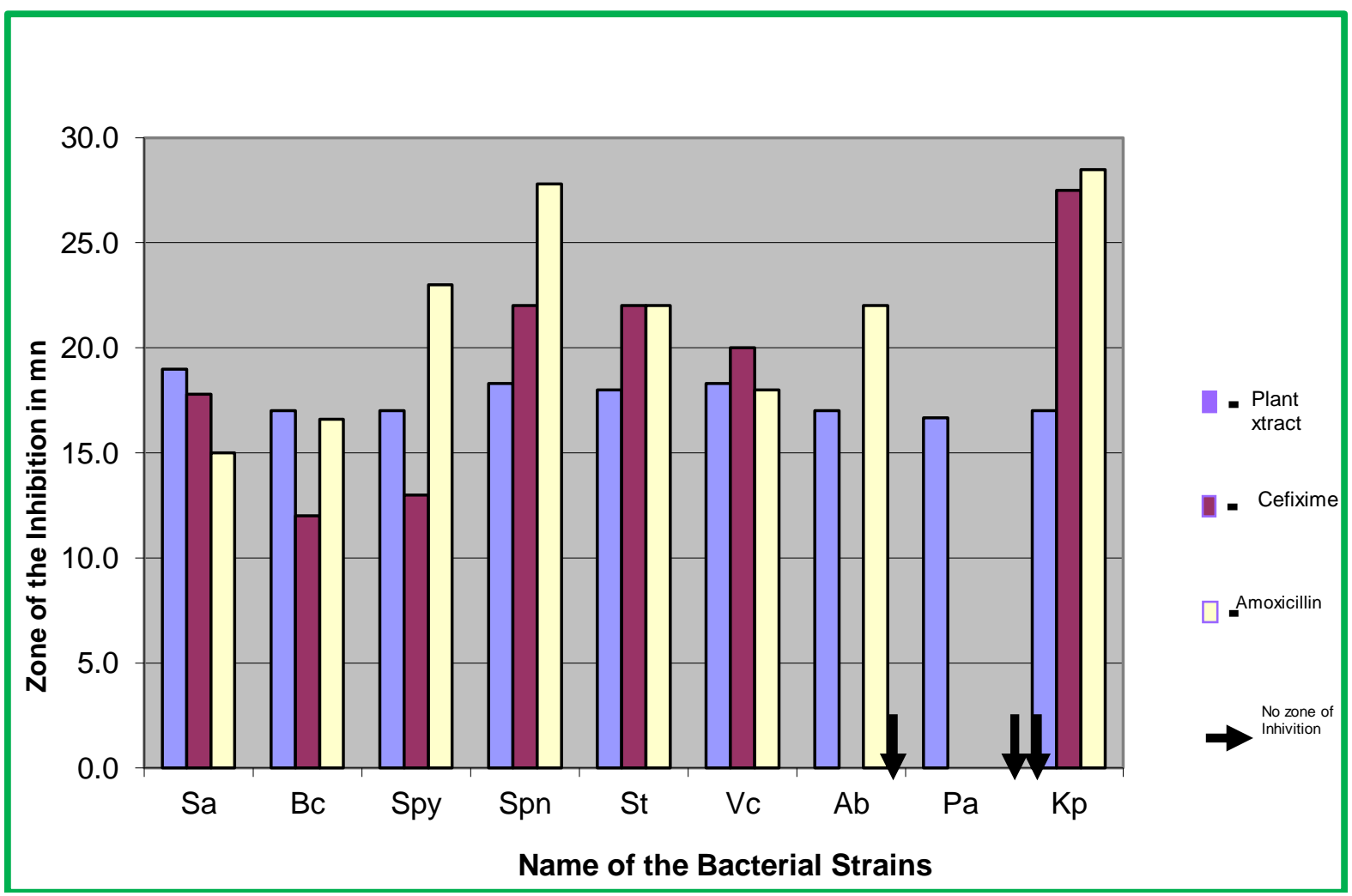

Figure3: Comparision of anti bactiral activity of P.zeylanicawith anitibiotics 
Plant extract is considered to be therapeutically potential if it shows MIC value between $0.03 \mathrm{mg} / \mathrm{mL}$ to $200 \mathrm{mg} / \mathrm{mL}$ (NCCLS.2012). The current investigation found MIC values ranging from $5.0 \mathrm{mg} / \mathrm{mL}$ through 1.25 $\mathrm{mg} / \mathrm{mL}$. The higher the effectiveness of a plant extract like an antibacterial agent, the lesser the MIC value of plant extract. 3 bacteria, $V$. cholerae, A. baumannii, and P. aeruginosa, had the least MIC levels $(1.25 \mathrm{mg} / \mathrm{mL})($ Table 4$)$.

Table4: Minimum inhibitory concentration (MIC) of plans under study

\begin{tabular}{|c|c|c|c|c|c|c|c|c|c|c|c|}
\hline \multirow[t]{2}{*}{ S.No } & \multirow{2}{*}{$\begin{array}{c}\text { Name of the } \\
\text { plant }\end{array}$} & \multirow{2}{*}{$\begin{array}{c}\text { Name of } \\
\text { the extract }\end{array}$} & \multicolumn{9}{|c|}{ Minimum Inhibitory Concentration (MIC) in $\mathrm{mg} / \mathrm{mL}$} \\
\hline & & & S. a & C. pt & S. py & S. pn & S. $\mathbf{t}$ & V.c & A. b & P. $\mathbf{a}$ & K.p \\
\hline 1 & $\begin{array}{l}\text { Achyranthusasper } \\
\text { a }\end{array}$ & Methanol & 5.0 & 5.0 & 5.0 & 5.0 & 1.25 & 1.25 & 1.25 & 2.5 & 2.5 \\
\hline 2 & Blumeafistulosa & Methanol & 1.25 & 1.25 & 1.25 & 0.625 & 2.5 & 2.5 & 2.5 & 5.0 & 2.5 \\
\hline 3 & $\begin{array}{l}\text { Blumeasolidagino } \\
\text { ides }\end{array}$ & $\begin{array}{l}\text { Ethyle } \\
\text { acetate }\end{array}$ & 2.5 & 5.0 & 2.5 & 2.5 & 2.5 & 2.5 & 5.0 & 2.5 & 2.5 \\
\hline 4 & Clitoriaternatea & n-hexane & 2.5 & 2.5 & 2.5 & 2.5 & 1.25 & 1.25 & 1.25 & 1.25 & 1.25 \\
\hline 5 & Euphorbia indica & $\begin{array}{l}\text { Ethyle } \\
\text { acetate }\end{array}$ & 2.5 & 2.5 & 1.25 & 2.5 & 2.5 & 1.25 & 1.25 & 2.5 & 2.5 \\
\hline 6 & $\begin{array}{l}\text { Hydrocotylerotun } \\
\text { difolia }\end{array}$ & Methanol & 5.0 & 5.0 & 5.0 & 5.0 & 2.5 & 5.0 & 5.0 & 1.25 & 1.25 \\
\hline 7 & $\begin{array}{l}\text { Leonotisnepetifoli } \\
\text { a }\end{array}$ & Methanol & 1.25 & 1.25 & 2.5 & 2.5 & 5.0 & 5.0 & 5.0 & 5.0 & 5.0 \\
\hline 8 & Pavoniazylenica & Methanol & 5.0 & 5.0 & 5.0 & 5.0 & 1.25 & 1.25 & 1.25 & 2.5 & 2.5 \\
\hline 9 & Quisqualisindica & Ethanol & 1.25 & 1.25 & 1.25 & 1.25 & 1.25 & 1.25 & 0.625 & 0.3125 & 0.625 \\
\hline 10 & $\begin{array}{l}\text { Solanumsurattens } \\
e\end{array}$ & Methanol & 5.0 & 2.5 & 2.5 & 5.0 & .5 .0 & 5.0 & 2.5 & 1.25 & 2.5 \\
\hline 11 & Azythromycin & Water & 0.3125 & 0.625 & 0.625 & 0.156 & 0.156 & 0.156 & NA & NA & 0.078 \\
\hline 12 & Amoxicillin & Water & 0.3125 & $\begin{array}{c}0.312 \\
5\end{array}$ & 0.156 & 0.078 & 0.156 & $\begin{array}{c}0.312 \\
5\end{array}$ & 0.156 & NA & 0.078 \\
\hline
\end{tabular}

\section{Conclusion:}

P. zeylanicaprocesses excellent antibacterial properties against Broad spectrum antibiotics, azythromycin and amoxicillin. The RPI values of methanol extract is high against B.coagulans $(127.5 \%)$ followed by S.pyrogenes $(115.38 \%)$ andV.cholerae $(113.0 \%)$ its effectiveness is lesser to that ofazythromycinover other bacterial strains in the study. When tried to compare with the antibiotic Amoxicillin, the methanol extract RPI against V.cholerae is 125.55 percent, trailed by 108.00 percent for S. typhi. Another noteworthy feature of this extract is its ability to kill bacteria such as A. baumannii $-20.60 \pm 57 \mathrm{~mm}$ and P.aeruginosa $-18.60 \pm 57 \mathrm{~mm}$, which are resistant to conventional antibiotics. Plant extract has MIC values ranging from $5.0 \mathrm{mg} / \mathrm{mL}$ to $1.25 \mathrm{mg} / \mathrm{mL}$. The plant extract is extremely efficient over three bacteria: V. cholerae, A. baumannii, and P. aeruginosa $(1.25 \mathrm{mg} / \mathrm{mL})$. 


\section{References:}

1. Swarnalatha, K., Ramya, K.P., Sunitha, K., Hari Babu, B. (2018). A quantitative estimation of phytochemicals, anti-Diabetic and anti-oxidant activities of crude extracts of Sphagneticolatrilobata (L.) and Adathodavasica Linn., J. Nat. Prod Resour, 4(1):155-159.

2. Babu, A.V., Sujatha, K., Srikanaka, V., Narayana, K.J.P., Hari Babu, B., Satyanarayana, P.V.V. (2009). Anticancer and anti-inflammatory activities of extracts of Merremiaemarginata. Biosci. Biotechnol. Res. Asia, 6(2): 835-838.

3. Babu, A.V., Rao, R.S.C., Hari Babu B., Gottumukkala, V.S. (2013). Isolation and bioactivity of diacetyltetritol from Merremiaemarginata(Burm.f). Nat Prod: An Indian Journal, 9(5):201-208.

4. Chandu, C., Sharmila, N., Hari Babu, B. (2017).A Facile Green Reduction for Graphene-Silver Nanocomposite Using Betel Leaf Extract for the Photocatalytic Degradation of Water Pollutants. Chemistry Select, 34(2): 11172-11176.

5. VenkataRamana, K., SwarnaLatha, K., Ravindranath, K., Hari Babu, B. (2017). Methyl red dye removal using new bio-sorbents derived from Hyacinth and TinosporaCorifolia plants from waste water.Rasayan J.Chem, 10 (2):349-362.

6. Aja, P.M., Ezeudeh, N.J., Umahi, B.G., Ugwu-Okechukwu, P.C., Enechi, O.C., Nweke, O.L., Patience, N.O. (2016). Hepato-protective effect of ethanol extract of Pterocarpussantalinoides leaf on carbon tetrachloride (CCl4) induced albino rats. Carib. j. SciTech, 4:882-895.

7. Ceylon Swamp Mallow, flowersofindia.net, Accessed on 2017, available at http://www.flowersofindia.net/catalog/slides/Ceylon\%20Swamp\%20Mallow.html

8. Cos, P., Vlietinck, A.J., Berghe, D.V., Maes, L. (2006). Anti-infective potential of natural products: How to develop a stronger in vitro 'proof of- concept. J. Ethno Pharmacol, 106: 290-302.

9. Alade, P.I., Irobi, O.N. (1993). Antimicrobial activities of crude leaf extracts of Acalyphawilkensiana. J.Ethnopharmacol, 39 (3): 171-174.

10. Venkata Raman, B., Bhaskar Reddy, I., Rama Rao, M., Sivakumar, K., Rajagopal, S. V. (2008). Antibacterial activity of Lippiacitriodora:A folklore plant. J. Pure Appl.Microbiol, 2(1): 249 - 252.

11. Venkata Raman, B., Sai Ramkishore, A., Uma Maheswari, M.,Radhakrishnan, T.M. (2009). Antibacterial Activities of Some Folklore Medicinal Plants of Eastern Ghats. J. Pure Appl.Microbiol, 3(1):187-194.

12. Cowman, M.M. (1999). Plant products as antimicrobial agents. Clin.Microbio. Rev, 12: 561-582.

13. Naz, R.,Bano, A. (2012). Antimicrobial potential of Ricinuscommunis leaf extracts in different solvents against pathogenic bacterial and fungal strains. Asian Pac. J. Trop. Biomed, 2(12): 944-947.

14. Valgas, C, De Souza, S.M., Smânia, E.F.A., Smânia, Jr. A. (2007) Screening methods to determine antibacterial activity of natural products. Braz. J. Microbiol., 38(2): 369-380. 